\title{
Yield performance of soybean and corn subjected to magnesium foliar spray
}

\author{
Lucas Miguel Altarugio(1), Marcos Harm Loman(1), Matheus Gomes Nirschl(1), \\ Rafael Gil Silvano(2), Eduardo Zavaschi ${ }^{(1)}$, Leandro de Mello e Silva Carneiro(3), \\ Godofredo Cesar Vitti(1), Pedro Henrique de Cerqueira Luz ${ }^{(4)}$ and Rafael Otto(1)
}

\begin{abstract}
(1)Universidade de São Paulo (USP), Escola Superior de Agricultura Luiz de Queiroz, Avenida Pádua Dias, no 11, CEP 13418-900 Piracicaba, SP, Brazil. E-mail: lucas.altarugio@usp.br, marcos.loman@usp.br, matheus.nirschl@gmail.com, eduzavaschi@yahoo.com.br, gcvitti@usp.br, rotto@usp.br (2)Produquímica Indústria e Comércio, Avenida Paulista, № 1.754, $3^{\circ}$ andar, Cerqueira César, CEP $01310-920$ São Paulo, SP, Brazil. E-mail: rafael.gsilvano@gmail.com ${ }^{(3)}$ Agro Industrial Eldorado, Rua Alexandre Aliperti, no 340, CEP $04156-110$ São Paulo, SP, Brazil. E-mail: leandromscarneiro@hotmail.com ${ }^{(4)}$ USP, Faculdade de Zootecnia e Engenharia de Alimentos, Avenida Duque de Caxias Norte, no 225, CEP 13635-900 Pirassununga, SP, Brazil. E-mail: phcerluz@usp.br
\end{abstract}

\begin{abstract}
The objective of this work was to evaluate the effect of magnesium foliar spray on yield performance of soybean (Glycine max) and corn (Zea mays) cultivated in soil with adequate levels of base saturation and magnesium content in Brazil. The field trials were conducted on a Typic Hapludox cultivated with soybean and corn in the 2013/2014 and 2014/2015 crop seasons, respectively. Treatments consisted of Mg rates (50, 100, 250, 500, 1,000 and 1,500 $\mathrm{g} \mathrm{ha}^{-1}$ and a control without $\mathrm{Mg}$ ) applied during the $\mathrm{V} 4$, R1, and R5.1 (soybean) or V4 and R2 (corn) phenological growth stages as magnesium sulfate heptahydrate $\left(\mathrm{MgSO}_{4} \cdot 7 \mathrm{H}_{2} \mathrm{O}\right)$. The SPAD index, leaf $\mathrm{Mg}$ content, grain yield, and 100-grain weight were evaluated. The $\mathrm{Mg}$ foliar spray increased the SPAD index in soybean and the leaf Mg content in corn. The Mg rates of 540 and $890 \mathrm{~g} \mathrm{ha}^{-1}$ increased in 325 and $737 \mathrm{~kg} \mathrm{ha}^{-1}$ the yield performance of soybean and corn, respectively, regardless of the phenological growth stages. The Mg application during the reproductive stages increased in $2 \%$ the 100 -grain weight for both crops. Foliar spraying of $\mathrm{Mg}$ improves the yield performance in soybean and corn crops.
\end{abstract}

Index terms: Glycine max, Zea mays, foliar fertilization, magnesium sulfate.

\section{Desempenho produtivo de soja e milho submetidos à aplicação foliar de magnésio}

\begin{abstract}
Resumo - O objetivo deste trabalho foi avaliar o efeito da aplicação foliar de magnésio no desempenho produtivo de soja (Glycine max) e milho (Zea mays) em solo com níveis adequados de saturação por base e conteúdo de magnésio, no Brasil. Os experimentos foram desenvolvidos em Latossolo Vermelho-Amarelo distrófico cultivado com soja e milho nas safras 2013/14 e 2014/15, respectivamente. Os tratamentos consistiram de aplicação foliar de doses de $\mathrm{Mg}\left(50,100,250,500,1.000\right.$ e $1.500 \mathrm{~g} \mathrm{ha}^{-1}$ e controle sem $\left.\mathrm{Mg}\right)$ nos estádios fenológicos V4, R1 e R5.1 (soja) ou V4 e R2 (milho), na forma de sulfato de magnésio heptahidratado $\left(\mathrm{MgSO}_{4} \cdot 7 \mathrm{H}_{2} \mathrm{O}\right)$. Avaliaram-se o índice SPAD, teor foliar de $\mathrm{Mg}$, produtividade de grãos e massa de 100 grãos. A aplicação foliar de Mg aumentou o índice SPAD na cultura da soja e o teor foliar de Mg na cultura do milho. As doses de $\mathrm{Mg}$ de 540 e $890 \mathrm{~g} \mathrm{ha}^{-1}$ proporcionaram incrementos de 325 e $737 \mathrm{~kg} \mathrm{ha}^{-1}$ na produtividade da soja e do milho, respectivamente, independentemente do estádio fenológico. A aplicação foliar de Mg no estádio reprodutivo aumentou em $2 \%$ a massa de 100 grãos de ambas culturas. A pulverização foliar de Mg melhora os parâmetros produtivos das culturas de soja e milho.
\end{abstract}

Termos para indexação: Glycine max, Zea mays, adubação foliar, sulfato de magnésio.

\section{Introduction}

Magnesium is an essential element to plants, being a constituent of the chlorophyll molecule and acting in phosphorylation, translocation of photoassimilates and in the activation of multiple enzymes, such as glutathione synthetase and phosphoenolpyruvate (PEP) carboxylase. Crop growth and yield are highly affected by $\mathrm{Mg}$ deficiency in intensive agricultural production areas (Römheld \& Kirby, 2007). It should be noted that $\mathrm{Mg}$ is mainly provided by liming, which may not 
be supplying sufficient amounts of this element to the plants.

Several factors can cause $\mathrm{Mg}$ deficiency in plants, such as a low Mg concentration in soil-forming rocks, $\mathrm{Mg}$ losses in the soil (Maathuis, 2009; Gransee \& Führs, 2013), and the planting of successive crops with unbalanced $\mathrm{Mg}$ fertilization relative to the crop $\mathrm{Mg}$ uptake (Pol \& Traore, 1993). Even in soils with adequate $\mathrm{Mg}$ levels, Mg deficiency may occur due to excessive acidity, high levels of aluminium or manganese, salinity, low water availability in the soil, and low plant transpiration (Mengel \& Kirby, 2001; Lynch \& St. Clair, 2004; Gransee \& Führs, 2013). Moreover, high levels of $\mathrm{Mg}$ in the soil can inhibit the absorption of zinc and $\mathrm{Mn}$ causing the deficiency of these elements (Moreira et al., 2003). Fertilization with high potassium levels can also result in $\mathrm{Mg}$ deficiency once $\mathrm{K}$ inhibits $\mathrm{Mg}$ absorption by plants (Guiet-Bara et al., 2007).

The foliar spraying of $\mathrm{Mg}$ provides a means of addressing the increasing occurrence of $\mathrm{Mg}$ deficiency in crops. Foliar nutrient application can be a good strategy to increase crop yield, help in soil supplementation, and generate response in a short period of time (Fageria et al., 2009). Jezek et al. (2015) observed an increased leaf $\mathrm{Mg}$ content, SPAD index, photosynthetic rate, and accumulation of shoot biomass in corn (Zea mays) subjected to a foliar spray of $\mathrm{Mg}$ under controlled conditions. Positive effects on crop yield from spraying foliage with $\mathrm{Mg}$ were observed in sugar beet (Beta vulgaris L.) (Barlog \& Grzebisz, 2001), soybean (Glycine max) (Vrataric et al., 2006), and fava bean (Vicia faba) (Neuhaus et al., 2014).

Few studies have assessed the effects of foliar fertilization on crop quality and yield, especially in annual crops such as soybean and corn (Gerendás \& Führs, 2013). Considering the positive effect of $\mathrm{Mg}$ on the translocation of photoassimilates and carbohydrates in plants (Cakmak \& Yazici, 2010), it is possible that the foliar spraying of $\mathrm{Mg}$ during the reproductive period would increase grain filling and yield in soybean and corn crops.

The objective of this work was to evaluate the effect of $\mathrm{Mg}$ foliar spray on yield performance of soybean and corn cultivated in soil with adequate levels of base saturation and magnesium content in Brazil.

\section{Materials and Methods}

The experiments were carried out in the municipality of Uberlândia $\left(19^{\circ} 25^{\prime} \mathrm{S}, 47^{\circ} 59^{\prime} \mathrm{W}\right.$, at an altitude of $700 \mathrm{~m}$ ), in the state of Minas Gerais, Brazil, in the 2013/2014 and 2014/2015 crop seasons with soybean and corn, respectively. The climate of the region is classified as Cwa, according to Köppen's classification, which is characterized as a wet tropical climate with a rainy season in the summer, dry season in the winter, and average monthly temperature between 18 and $22^{\circ} \mathrm{C}$. The rainfall and mean monthly temperature data from September to May for the 2013/2014 and $2014 / 2015$ crop seasons in the experimental areas are shown in Figure 1.

The experimental areas had been cultivated in a no-tillage system for 11 years, with corn or soybean as the first crop and wheat (Triticum aestivum), oat (Avena strigosa), or pearl millet (Pennisetum glaucum) in succession. The soil of the experimental areas is classified as Latossolo Vermelho-Amarelo distrófico (Typic Hapludox) according to Santos et al. (2006), and the soil chemical properties (Raij et al., 2001; Vitti, 1989) and textural attributes (Camargo et al., 1986) are listed in Table 1.

Soybean cultivar AN 5909 RGN was sown on $10 / 18 / 2013$, in a $7 \times 3$ factorial arrangement, with seven $\mathrm{Mg}$ rates (a control without $\mathrm{Mg}$ and 25, 50, 100, 250, 500 and $1,000 \mathrm{~g} \mathrm{ha}^{-1}$ ), three application times (at phenological stages: V4, with four trifoliate leaves; R1, at the beginning of flowering; and R5.1, at the beginning of grain filling), and five replicates in a randomized complete block design. The corn (hybrid P30F53 HX Waxy) was sown on $11 / 10 / 2014$, in a $7 \times 2$ factorial arrangement, with seven $\mathrm{Mg}$ rates (a control without $\mathrm{Mg}$ and 50, 100, 250, 500, 1,000 and 1,500 $\mathrm{g} \mathrm{ha}^{-1}$ ), two application times (during phenological stage V4, with four fully developed leaves, or during $\mathrm{R} 2$, the milk stage) and six replicates in a randomized complete block design. For both crops, the experimental units consisted of ten 15-m long planting rows that were spaced $0.5 \mathrm{~m}$ apart. The $\mathrm{Mg}$ source used for the foliar fertilization was magnesium sulfate heptahydrate $\left(\mathrm{MgSO}_{4} \cdot 7 \mathrm{H}_{2} \mathrm{O}\right.$ containing $9 \% \mathrm{Mg}$ ), which was applied in solution at a spray rate of $300 \mathrm{~L} \mathrm{ha}^{-1}$ using a $\mathrm{CO}_{2}$-pressurized sprayer.

Before setting up the experiments, the following surface applications were conducted without incorporation: $1.3 \mathrm{Mg} \mathrm{ha}^{-1}$ dolomitic lime, as well as $0.5 \mathrm{Mg} \mathrm{ha}^{-1}$ agricultural gypsum, in the soybean 
experiment and $2.0 \mathrm{Mg} \mathrm{ha}^{-1}$ dolomitic lime and 0.5 $\mathrm{Mg} \mathrm{ha} \mathrm{a}^{-1}$ agricultural gypsum in the corn experiment; both applications were carried three months before planting. During the pre-sowing period of the soybean crop, 12, 60, 30, and $0.33 \mathrm{~kg} \mathrm{ha}^{-1} \mathrm{~N}, \mathrm{P}_{2} \mathrm{O}_{5}$, $\mathrm{K}_{2} \mathrm{O}$, and $\mathrm{B}$, respectively, were applied. For the corn experiment, 25, 120, 75, and $0.77 \mathrm{~kg} \mathrm{ha}^{-1} \mathrm{~N}, \mathrm{P}_{2} \mathrm{O}_{5}, \mathrm{~K}_{2} \mathrm{O}$, and $\mathrm{B}$, respectively, were applied during pre-sowing. Moreover, $190 \mathrm{~kg} \mathrm{ha}^{-1} \mathrm{~N}$ fertilizer was applied as top dressing during the V4 phenological stage. Soil liming and fertilization were performed according to Sousa \& Lobato (2004).

To determine the $\mathrm{Mg}$ concentration of the crops, leaves were collected when the soybean and corn plants were at the R6 and R2 phenological growth

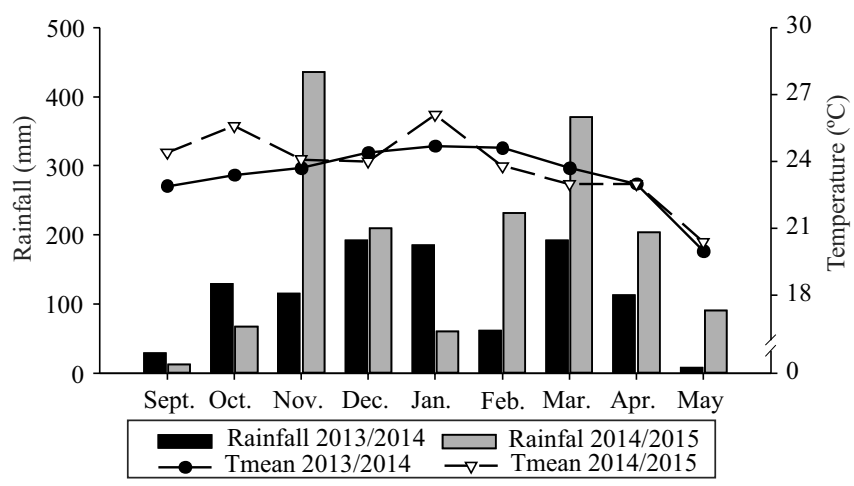

Figure 1. Monthly rainfall and mean temperature (Tmean) in the 2013/2014 and 2014/2015 corn (Zea mays) and soybean (Glycine max) crop seasons, respectively in the municipality of Uberlândia, in the state of Minas Gerais, Brazil. stages, respectively. The collection of soybean leaves occurred later than that of corn leaves because the last foliar spraying in soybean was performed at the R5 phenological stage, whereas the corn leaves were collected one week after the last foliar application (at $\mathrm{R} 2$ ). The collected leaves were the third fully developed trifoliate leaf counting from the apex of the soybean plant and the first corn leaf opposite the top ear. The leaf collection and $\mathrm{Mg}$ analysis procedures followed Malavolta et al. (1997). In both experiments, the leaves of ten plants were sampled per experimental unit. Before leaf collection, the SPAD index was determined in the same corn and soybean leaves that were collected for evaluating the $\mathrm{Mg}$ concentration. The index was determined with the SPAD 502 chlorophyll meter (Minolta Corp., Ramsey, Japan), which allows the leaf chlorophyll content values to be obtained indirectly in a non-destructive manner (Waskom et al., 1996).

The grain yield in both experiments was obtained by harvesting and weighing of the grains from ten central metres within four rows per experimental unit. Of the total grains harvested from each experimental unit, a subsample was collected to obtain the 100 -grain weight with $13 \%$ moisture.

The data were subjected to the analysis of variance using the F-test, at the 5 and $10 \%$ probability levels. When the analysis of variance yielded significant results, the means were compared using Tukey's test, at $10 \%$ probability, and a regression analysis was conducted to evaluate the rate effects using the Sisvar statistical software (Ferreira, 2011).

Table 1. Chemical and physical characteristics of soils collected at the layers of 0-20, 20-40 cm in the experimental areas of soybean (Glycine max) and corn (Zea mays) in the municipality of Uberlândia, in the state of Minas Gerais, Brazil ${ }^{(1)}$.

\begin{tabular}{|c|c|c|c|c|c|c|c|c|c|c|c|c|c|c|c|c|c|c|c|c|c|}
\hline $\begin{array}{l}\text { Soil layer } \\
(\mathrm{cm})\end{array}$ & $\begin{array}{c}\mathrm{pH} \\
\mathrm{CaCl}_{2}\end{array}$ & $\begin{array}{c}\text { SOM } \\
\left(\mathrm{g} \mathrm{dm}^{-3}\right)\end{array}$ & $\begin{array}{c}\mathrm{P} \\
(\mathrm{mg} \mathrm{d}\end{array}$ & $\begin{array}{c}\mathrm{S} \\
\left.\mathrm{m}^{-3}\right)\end{array}$ & $\mathrm{Ca}$ & $\mathrm{Mg}$ & K & $\mathrm{mmc}$ & $\begin{array}{l}\mathrm{H}+\mathrm{Al} \\
\left.\mathrm{lc}_{\mathrm{c}} \mathrm{dm}^{-3}\right)-\end{array}$ & SB & CEC & \multicolumn{2}{|c|}{$--(\%)---$} & B & $\mathrm{Cu}$ & $\operatorname{g~dm}$ & $\mathrm{Mn}$ & ---- & \multicolumn{3}{|c|}{-----( $\left(\mathrm{g} \mathrm{kg}^{-1}\right)^{-----}$} \\
\hline & \multicolumn{21}{|c|}{ Soybean } \\
\hline $0-20$ & 5.2 & 23 & 26 & 18 & 35 & 8 & 2.5 & 0 & 31 & 45.5 & 76.0 & 60 & 0.0 & 0.5 & 0.8 & 32 & 1.2 & 1.5 & 121 & 29 & 850 \\
\hline $20-40$ & 5.0 & 14 & 11 & 80 & 17 & 4 & 1.9 & 0 & 34 & 22.9 & 56.9 & 40 & 0.0 & 0.5 & 0.7 & 23 & 0.5 & 0.6 & 116 & 22 & 862 \\
\hline & \multicolumn{21}{|c|}{ Corn } \\
\hline $0-20$ & 5.4 & 20 & 6 & 26 & 43 & 18 & 1.3 & 0 & 67 & 62.3 & 129.0 & 48 & 0.0 & 0.9 & 6.0 & 39 & 4.8 & 3.3 & 178 & 16 & 806 \\
\hline $20-40$ & 4.9 & 15 & 2 & 43 & 26 & 12 & 0.9 & 2 & 83 & 38.9 & 122.0 & 32 & 5.0 & 0.7 & 6.3 & 50 & 4.8 & 3.4 & 154 & 90 & 756 \\
\hline
\end{tabular}

${ }^{(1)} \mathrm{pH}, \mathrm{CaCl}_{2}$ 0,01 mol L-1; SOM, soil organic matter; $\mathrm{P}$, extracted by anion and cation exchangeable resin; $\mathrm{S}$, extracted with $\mathrm{Ca}\left(\mathrm{H}_{2} \mathrm{PO}_{4}\right)_{2} 0,01 \mathrm{~mol} \mathrm{~L}-1 \mathrm{Ca}^{-1}$ $\mathrm{Mg}$, and $\mathrm{K}$, extracted by anion and cation exchangeable resin; H+Al, pH SMP; SB, sum of bases; CEC, cation exchange capacity; BS, base saturation; m, aluminium saturation. $\mathrm{B}$, extracted with hot water; and $\mathrm{Cu}, \mathrm{Fe}, \mathrm{Mn}$, and $\mathrm{Zn}$, extracted with DTPA. 


\section{Results and Discussion}

In soybean, the $\mathrm{Mg}$ foliar spray increased the SPAD index linearly with increases in the $\mathrm{Mg}$ rate (Table 2). This result can be explained by the increase in chlorophyll, since magnesium is the center of the molecule. $\mathrm{Mg}$ foliar spraying also increased the chlorophyll concentration in a study by Teklić et al. (2009), who observed an increase in the SPAD index with the Mg spraying. Despite the significant effect on the SPAD index in the present study, the Mg content in soybean leaves did not vary with the $\mathrm{Mg}$ rates or application times. The late collection of soybean leaves (during the R6 phenological stage) could have been responsible for the absence of increased $\mathrm{Mg}$ levels in the leaves receiving the foliar $\mathrm{Mg}$ fertilization, probably because $\mathrm{Mg}$ is not only quickly absorbed by leaves but also mobile in the phloem, and thus redistributed to other plant compartments (Hermans \& Verbruggen, 2005; Guo et al., 2016).

The Mg rate quadratically affected soybean yield, regardless of the application time (Table 3). The

Table 2. SPAD index and foliar Mg content in the soybean (Glycine max) crop fertilized with rates of $\mathrm{Mg}$ foliar spraying in different phenological stages (V4, R1, and R5.1) in the municipality of Uberlândia, in the state of Minas Gerais, Brazil.

\begin{tabular}{|c|c|c|c|c|c|c|c|c|}
\hline \multirow{2}{*}{$\begin{array}{l}\text { Mg foliar spray } \\
\left(\mathrm{g} \mathrm{ha}^{-1}\right)\end{array}$} & \multicolumn{3}{|c|}{ SPAD index } & \multirow[t]{2}{*}{ Mean } & \multicolumn{3}{|c|}{$\mathrm{Mg}$ content $\left(\mathrm{g} \mathrm{kg}^{-1}\right)$} & \multirow[t]{2}{*}{ Mean } \\
\hline & V4 & $\mathrm{R} 1$ & R5.1 & & $\mathrm{V} 4$ & $\mathrm{R} 1$ & R5.1 & \\
\hline 0 & 38.3 & 38.3 & 38.3 & 38.3 & 3.31 & 3.31 & 3.31 & 3.31 \\
\hline 25 & 40.7 & 39.2 & 41.2 & 40.4 & 3.26 & 3.19 & 3.17 & 3.20 \\
\hline 50 & 39.3 & 43.2 & 42.2 & 41.6 & 3.10 & 3.10 & 3.19 & 3.13 \\
\hline 100 & 40.9 & 41.3 & 42.6 & 41.6 & 3.18 & 3.18 & 3.00 & 3.11 \\
\hline 250 & 40.1 & 40.4 & 42.3 & 40.9 & 3.16 & 3.41 & 3.46 & 3.33 \\
\hline 500 & 41.1 & 42.2 & 42.8 & 41.7 & 3.04 & 3.19 & 3.25 & 3.16 \\
\hline 1,000 & 42.5 & 41.9 & 42.1 & 42.2 & 3.14 & 3.02 & 3.17 & 3.11 \\
\hline Mean & 40.4 & 40.9 & 41.5 & - & 3.17 & 3.20 & 3.21 & - \\
\hline $\mathrm{P}_{\text {rate }}$ & \multicolumn{4}{|c|}{$0.0619 *$} & \multicolumn{4}{|c|}{$0.684^{\mathrm{ns}}$} \\
\hline$P_{\text {stage }}$ & \multicolumn{4}{|c|}{$0.4441^{\mathrm{ns}}$} & \multicolumn{4}{|c|}{$0.220^{\mathrm{ns}}$} \\
\hline$P_{\text {rate } x \text { stage }}$ & \multicolumn{4}{|c|}{$0.9682^{\text {ns }}$} & \multicolumn{4}{|c|}{$0.549^{\mathrm{ns}}$} \\
\hline $\mathrm{R}^{2}$, linear regression & \multicolumn{4}{|c|}{0.35} & \multicolumn{4}{|c|}{ ns } \\
\hline $\mathrm{R}^{2}$, quadratic regression & \multicolumn{4}{|c|}{$\mathrm{ns}$} & \multicolumn{4}{|c|}{$\mathrm{ns}$} \\
\hline Coefficient of variation (\%) & \multicolumn{4}{|c|}{8.6} & \multicolumn{4}{|c|}{7.5} \\
\hline
\end{tabular}

Table 3. Grain yield and 100-grain weight in the soybean (Glycine max) crop fertilized with rates of $\mathrm{Mg}$ foliar spray in different phenological stages in the municipality of Uberlândia, in the state of Minas Gerais, Brazil(1).

\begin{tabular}{|c|c|c|c|c|c|c|c|c|}
\hline \multirow{2}{*}{$\begin{array}{l}\text { Mg foliar spray } \\
\left(\mathrm{g} \mathrm{ha}^{-1}\right)\end{array}$} & \multicolumn{3}{|c|}{ Grain yield $\left(\mathrm{kg} \mathrm{ha}^{-1}\right)$} & \multirow[t]{2}{*}{ Mean } & \multicolumn{3}{|c|}{ 100-grain weight $(\mathrm{g})$} & \multirow[t]{2}{*}{ Mean } \\
\hline & V4 & R1 & R5.1 & & V4 & $\mathrm{R} 1$ & R5.1 & \\
\hline 0 & 4,245 & 4,245 & 4,245 & 4,245 & $15.1 \mathrm{a}$ & $15.1 \mathrm{a}$ & $15.1 \mathrm{a}$ & 15.1 \\
\hline 25 & 4,400 & 3,905 & 4,282 & 4,196 & $14.5 \mathrm{~b}$ & $15.0 \mathrm{ab}$ & $15.4 \mathrm{a}$ & 15.0 \\
\hline 50 & 4,199 & 4,190 & 4,359 & 4,250 & $15.0 \mathrm{~b}$ & $15.2 \mathrm{ab}$ & $15.4 \mathrm{a}$ & 15.0 \\
\hline 100 & 4,334 & 4,513 & 4,322 & 4,390 & $15.2 \mathrm{a}$ & $15.3 \mathrm{a}$ & $15.2 \mathrm{a}$ & 15.2 \\
\hline 250 & 4,547 & 4,641 & 4,398 & 4,529 & $15.0 \mathrm{a}$ & $15.1 \mathrm{a}$ & $14.9 \mathrm{a}$ & 15.0 \\
\hline 500 & 4,385 & 4,473 & 4,699 & 4,519 & $15.1 \mathrm{~b}$ & $15.4 \mathrm{a}$ & $15.5 \mathrm{a}$ & 15.1 \\
\hline 1,000 & 4,341 & 4,071 & 4,555 & 4,323 & $15.0 \mathrm{a}$ & $14.8 \mathrm{a}$ & $15.3 \mathrm{a}$ & 15.0 \\
\hline Mean & 4,350 & 4,291 & 4,409 & - & $14.9 \mathrm{~b}$ & $15.1 \mathrm{ab}$ & $15.2 \mathrm{a}$ & - \\
\hline $\mathrm{P}_{\text {rate }}$ & \multicolumn{4}{|c|}{$0.081^{*}$} & \multicolumn{4}{|c|}{$0.897^{\mathrm{ns}}$} \\
\hline $\mathrm{P}_{\text {stage }}$ & \multicolumn{4}{|c|}{$0.419^{\mathrm{ns}}$} & \multicolumn{4}{|c|}{$0.054 *$} \\
\hline$P_{\text {rate x stage }}$ & \multicolumn{4}{|c|}{$0.466^{\text {ns }}$} & \multicolumn{4}{|c|}{$0.060 *$} \\
\hline $\mathrm{R}^{2}$, linear regression & \multicolumn{4}{|c|}{ ns } & \multicolumn{4}{|c|}{ ns } \\
\hline $\mathrm{R}^{2}$, quadratic regression & \multicolumn{4}{|c|}{$0.87, y=-0.0012 x^{2}+1.2942 x+4,221.6$} & \multicolumn{4}{|c|}{ ns } \\
\hline Coefficient of variation (\%) & \multicolumn{4}{|c|}{8.5} & \multicolumn{4}{|c|}{3.5} \\
\hline
\end{tabular}


obtained equation $\left(\mathrm{R}^{2}=0.87, \mathrm{p}<0.10\right)$ enabled an estimation of the $\mathrm{Mg}$ rate required to maximize the soybean yield. Calculations using the regression model indicate that a rate of $540.8 \mathrm{~g} \mathrm{ha}^{-1} \mathrm{Mg}$ would enable a maximum yield $\left(4,570 \mathrm{~kg} \mathrm{ha}^{-1}\right)$, which is approximately $8 \%$ higher than the control yield $\left(4,245 \mathrm{~kg} \mathrm{ha}^{-1}\right)$, corresponding to a gain of $325 \mathrm{~kg} \mathrm{ha}^{-1}$. Vrataric et al. (2006) obtained similar results, with increases of up to $9 \%$ in soybean yield after the foliar spraying of $\mathrm{Mg}$. Teklić et al. (2009) also observed a significant effect of $\mathrm{Mg}$ foliar spraying on soybean yield; Reinbott \& Blevins (1995) observed a positive effect as well, but with the joint application of $\mathrm{B}$ and $\mathrm{Mg}$, which they attributed to the increase in the number of branches and pods on the main stem. Another explanation could involve the promotion of soybean grain filling. The $\mathrm{Mg}$ foliar spray during the R1 or R5.1 stages increased the 100 -grain weight in soybean. However, this increase in the 100-grain weight was only dependent on the stage of $\mathrm{Mg}$ application, with no $\mathrm{Mg}$ rate effect. The yield increase observed in the present study could be related to the increased photosynthesis (evidenced by the increase in the SPAD index). This resulted in greater soybean shoot growth and increased crop yield components.

Although no significant effect of the Mg rate on the 100-grain weight was observed, a significant effect occurred not only for the application time but also for the interaction between application time and rate. The interaction analysis showed that, for the rates of 25, 50, and $500 \mathrm{~g} \mathrm{ha}^{-1} \mathrm{Mg}$, the applications during the R1 or R5.1 stage resulted in a greater 100-grain weight than that obtained with the application at the vegetative stage (V4). One of the known Mg effects on plant nutrition is the translocation of photo assimilates and carbohydrates in the plant (Cakmak \& Yazici, 2010). The increase in the 100-grain weight resulting from the application of $\mathrm{Mg}$ during the R1 and R5.1 stages may involve increased carbohydrate translocation induced by $\mathrm{Mg}$.

In the corn crop, the $\mathrm{Mg}$ foliar spray did not increase the SPAD index but increased the leaf $\mathrm{Mg}$ content (Table 4). This result was the opposite of that observed for the soybean crop (Table 2). The observed differences may be related to the variation in the response of the two crops to Mg. Teklic et al. (2009) found that soybean cultivars vary in their response to $\mathrm{Mg}$ applied as a foliar spray. According to the authors these differences most likely ocurred due to difference between the crops in the stage at which their leaves were collected for the quantification of the SPAD index and the leaf $\mathrm{Mg}$ content. The corn leaves were collected during the R2 stage soon after $\mathrm{Mg}$ application (in V4 or R1), whereas the soybean measurements were performed later, at stage R6. The higher Mg levels in the corn leaves from the plants treated with the $\mathrm{Mg}$ rates may, therefore, be related to the rapid absorption of the element by the leaves and its high mobility in the phloem (Fernández et al., 2015). Together, these factors may have resulted in the higher Mg levels in the corn evaluation, which was performed only one week after the $\mathrm{Mg}$ application, which can be shown by the linear increase in the levels of $\mathrm{Mg}$ with increasing rates of $\mathrm{Mg}$.

As verified for soybean, there was a significant effect of the $\mathrm{Mg}$ rate on corn yield (Table 5), regardless of the application time, with the $\mathrm{Mg}$ rate quadratically affecting the corn yield. The fitted equation $\left(\mathrm{R}^{2}=0.81\right.$, $\mathrm{p}<0.05)$ enabled the estimation of the $\mathrm{Mg}$ rate that would result in the maximum yield. Using the regression model, a rate of $888 \mathrm{~g} \mathrm{ha}^{-1} \mathrm{Mg}$ was predicted to result in the highest yield $\left(7,882 \mathrm{~kg} \mathrm{ha}^{-1}\right)$, which was

Table 4. SPAD index and foliar $\mathrm{Mg}$ content in the corn (Zea mays) crop fertilized with rates of $\mathrm{Mg}$ foliar spray in different phenological stages in the municipality of Uberlândia, in the state of Minas Gerais, Brazil.

\begin{tabular}{|c|c|c|c|c|c|c|}
\hline \multirow{2}{*}{$\begin{array}{l}\text { Mg foliar } \\
\text { spray }\left(\mathrm{g} \mathrm{ha}^{-1}\right)\end{array}$} & \multicolumn{2}{|c|}{ SPAD index } & \multirow[t]{2}{*}{ Mean } & \multicolumn{2}{|c|}{$\operatorname{Mg}\left(\mathrm{g} \mathrm{kg}^{-1}\right)$} & \multirow[t]{2}{*}{ Mean } \\
\hline & V4 & $\mathrm{R} 2$ & & V4 & $\mathrm{R} 2$ & \\
\hline 0 & 57.3 & 57.2 & 57.3 & 1.93 & 1.93 & 1.93 \\
\hline 250 & 58.6 & 59.1 & 58.8 & 1.85 & 2.13 & 1.99 \\
\hline 500 & 57.9 & 55.5 & 56.7 & 1.82 & 2.15 & 1.99 \\
\hline 1,000 & 51.7 & 58.8 & 55.3 & 2.28 & 2.18 & 2.23 \\
\hline 1,500 & 56.4 & 54.2 & 55.3 & 2.18 & 2.10 & 2.14 \\
\hline Mean & 56.4 & 57.0 & - & 2.01 & 2.10 & - \\
\hline $\mathrm{P}_{\text {rate }}$ & & $0.380^{\text {ns }}$ & & & $0.088^{*}$ & \\
\hline $\mathrm{P}_{\text {stage }}$ & & $0.666^{\mathrm{ns}}$ & & & $0.263^{\mathrm{ns}}$ & \\
\hline $\mathrm{P}_{\text {rate x stage }}$ & & $0.154^{\mathrm{ns}}$ & & & $0.229^{\text {ns }}$ & \\
\hline $\mathrm{R}^{2}-\mathrm{LR}$ & & $\mathrm{ns}$ & & & 68.8 & \\
\hline $\mathrm{R}^{2}-\mathrm{QR}$ & & ns & & & $\mathrm{ns}$ & \\
\hline CV (\%) & & 8.9 & & & 14.4 & \\
\hline
\end{tabular}

${ }^{n}$ Nonsignificant. *Significant at $10 \%$ probability. LR, linear regression; $\mathrm{QR}$, quadratic regression; and $\mathrm{CV}$, coefficient of variation. 
approximately $10 \%$ (or $737 \mathrm{~kg} \mathrm{ha}^{-1}$ ) higher than that observed for the control $\left(7,145 \mathrm{~kg} \mathrm{ha}^{-1}\right)$.

As in the soybean crop, the foliar spray of $\mathrm{Mg}$ also increased the 100-grain weight in the corn crop (Table 5). Moreover, a significant effect of $\mathrm{Mg}$ application time but not $\mathrm{Mg}$ rate occurred. In the case of corn, the $\mathrm{Mg}$ application at R1 resulted in a 100-grain weight of $34.6 \mathrm{~g}$, which exceeded the weight obtained when the application was performed at V4 (33.9 g). Gerendás \& Führs (2013) reported that $\mathrm{Mg}$ application generates better crop quality, but most of the studies do not elucidate the physiological mechanism involved in the response to $\mathrm{Mg}$. A favorable effect of the $\mathrm{Mg}$ foliar spray on the plant photosynthetic rate is possible because the foliar application of $\mathrm{Mg}$ has been associated with an increase in leaf chlorophyll content (Teklić et al., 2009).

The present study showed the positive impact of foliar $\mathrm{Mg}$ on the yield performance of the soybean and corn crops. It is important to underline that a positive effect of the $\mathrm{Mg}$ foliar application on the corn crop occurred even in soil containing adequate $\mathrm{Mg}$ content -18 and $12 \mathrm{mmol}_{\mathrm{c}} \mathrm{dm}^{-3}$ in the $0-20 \mathrm{~cm}$ and $20-40 \mathrm{~cm}$ layers,

Table 5. Grain yield and 100-grain weight in the corn (Zea mays) crop fertilized with rates of $\mathrm{Mg}$ foliar spraying in different phenological stages in the municipality of Uberlândia, in the state of Minas Gerais, Brazil ${ }^{(1)}$.

\begin{tabular}{|c|c|c|c|c|c|c|}
\hline \multirow{2}{*}{$\begin{array}{l}\text { Mg foliar } \\
\text { spray } \\
\left(\mathrm{g} \mathrm{ha}^{-1}\right)\end{array}$} & \multicolumn{2}{|c|}{$\begin{array}{c}\text { Grain yield } \\
\left(\mathrm{kg} \mathrm{ha}^{-1}\right)\end{array}$} & \multirow[t]{2}{*}{ Mean } & \multicolumn{2}{|c|}{$\begin{array}{l}\text { 100-grain } \\
\text { weight }(\mathrm{g})\end{array}$} & \multirow[t]{2}{*}{ Mean } \\
\hline & V4 & R2 & & V4 & $\mathrm{R} 2$ & \\
\hline 0 & 7,145 & 7,145 & 7,145 & 34.1 & 34.1 & 34.1 \\
\hline 250 & 7,447 & 7,878 & 7,662 & 33.5 & 35.3 & 34.4 \\
\hline 500 & 7,491 & 7,624 & 7,557 & 34.1 & 34.5 & 34.3 \\
\hline 1.000 & 7,696 & 8,248 & 7,972 & 34.0 & 34.9 & 34.5 \\
\hline 1.500 & 7,410 & 7,635 & 7,523 & 33.9 & 34.4 & 34.2 \\
\hline Mean & 7,438 & 7,706 & - & $33.9 \mathrm{~b}$ & $34.6 \mathrm{a}$ & - \\
\hline$P_{\text {rate }}$ & & $0.018^{*}$ & & & $0.724^{\text {ns }}$ & \\
\hline $\mathrm{P}_{\text {stage }}$ & & $0.228^{\mathrm{ns}}$ & & & $0.001^{*}$ & \\
\hline$P_{\text {rate x stage }}$ & & $0.448^{\text {ns }}$ & & & $0.110^{\text {ns }}$ & \\
\hline $\mathrm{R}^{2}-\mathrm{LR}$ & & $\mathrm{ns}$ & & & ns & \\
\hline $\mathrm{R}^{2}-\mathrm{QR}$ & & $0.81^{(2)}$ & & & ns & \\
\hline CV (\%) & & 7.5 & & & 2.4 & \\
\hline
\end{tabular}

${ }^{(1)}$ Means followed by different letters differ among phonological stages, by Tukey's test, at $10 \%$ probability. ${ }^{n s}$ Nonsignificant. *Significant at $10 \%$ probability. LR, linear regression; $\mathrm{QR}$, quadratic regression; $\mathrm{CV}$, coefficient of variation. ${ }^{(2)} y=-0.0009 x^{2}+1.5991 x+7,172.5$ respectively (Table 1). Two factors may have favored the positive response of the corn crop in soil already containing adequate $\mathrm{Mg}$ content: the competition of $\mathrm{Mg}$ and other nutrients may have occurred, and soil $\mathrm{Mg}$ may have been limited by a local water deficit that occurred in January (Figure 1). The water deficit that occurred at the beginning of the reproductive period may have limited soil $\mathrm{Mg}$ absorption during a period of intense $\mathrm{Mg}$ demand by corn (Ciampitti \& Vyn, 2013). A Mg foliar spray during the vegetative or reproductive periods proved to be a viable measure to improve plant nutrition and promote yield gains in soybean and corn crops.

\section{Conclusions}

1. Magnesium foliar spray favors and increases the SPAD index in soybean (Glycine max) and the leaf $\mathrm{Mg}$ content in corn (Zea mays).

2. Mg foliar spray, regardless of the phenological stage, promotes an increase in the grain yield of soybean and corn under the evaluated soil conditions.

3. The foliar spray of $\mathrm{Mg}$ during the reproductive stage increases the 100-grain weight in soybean and corn.

\section{Acknowledgments}

To Grupo de Apoio à Pesquisa e Extensão (Gape), for support in the field and laboratory activities; to S/A Agro Industrial Eldorado, for providing the experimental area and logistics support; to Produquímica Indústria e Comércio S.A., for funding the research; and to Conselho Nacional de Desenvolvimento Científico e Tecnológico (CNPq, process No. 308007/2016-6), for research productivity fellowship.

\section{References}

BARLOG, P.; GRZEBISZ, W. Effect of magnesium foliar application on the yield and quality of sugar beet roots. Rostlinná Výroba, v.47, p.418-422, 2001.

CAKMAK, I.; YAZICI, A.M. Magnesium: a forgotten element in crop production. Better Crops, v.94, p.23-25, 2010.

CAMARGO, A.O. de; MONIZ, A.C.; JORGE, J.A.; VALADARES, J.M.A.S. Métodos de análise química, mineralógica e física de solos do Instituto Agronômico de Campinas. Campinas: IAC, 1986. 94p. (IAC. Boletim técnico, 106).

CIAMPITTI, I.A.; VYN, T.J. Maize nutrient accumulation and partitioning in response to plant density and nitrogen rate: II. 
Calcium, Magnesium, and Micronutrients. Agronomy Journal, v.105, p.1645-1657, 2013. DOI: 10.2134/agronj2013.0126.

FAGERIA, N.K.; BARBOSA FILHO, M.P.; MOREIRA, A.; GUIMARÃES, C.M. Foliar fertilization of crop plants. Journal of Plant Nutrition, v.32, p.1044-1064, 2009. DOI: 10.1080/01904160902872826.

FERNÁNDEZ, V.; SOTIROPOULOS, T.; BROWN, P. Adubação foliar: fundamentos científicos e técnicas de campo. São Paulo: Abisolo, 2015. 150p.

FERREIRA, D.F. Sisvar: a computer statistical analysis system. Ciência e Agrotecnologia, v.35, p.1039-1042, 2011. DOI: 10.1590/ S1413-70542011000600001.

GERENDÁS, J.; FÜHRS, H. The significance of magnesium for crop quality. Plant and Soil, v.368, p.101-128, 2013. DOI: 10.1007/ s11104-012-1555-2.

GRANSEE, A.; FÜHRS, H. Magnesium mobility in soils as a challenge for soil and plant analysis, magnesium fertilization and root uptake under adverse growth conditions. Plant and Soil, v.368, p.5-21, 2013. DOI: 10.1007/s11104-012-1567-y.

GUIET-BARA, A.; DURLACH, J.; BARA, M. Magnesium ions and ionic channels: activation, inhibition or block - a hypothesis. Magnesium Research, v.20, p.100-106, 2007. DOI: 10.1684/ mrh.2007.0098.

GUO, W.; NAZIM, H.; LIANG, Z.; YANG, D. Magnesium deficiency in plants: an urgent problem. The Crop Journal, v.4, p.83-91, 2016. DOI: 10.1016/j.cj.2015.11.003.

HERMANS, C.; VERBRUGGEN, N. Physiological characterization of $\mathrm{Mg}$ deficiency in Arabidopsis thaliana. Journal of Experimental Botany, v.56, p.2153-2161, 2005. DOI: 10.1093/jxb/eri215.

JEZEK, M.; GEILFUS, C.-M.;; BAYER, A.; MÜHLING, K.-H. Photosynthetic capacity, nutrient status, and growth of maize (Zea mays L.) upon $\mathrm{MgSO}_{4}$ leaf-application. Frontiers in Plant Science, v.5, art. 781, 2015. DOI: 10.3389/fpls.2014.00781.

LYNCH, J.P.; ST. CLAIR, S.B. Mineral stress : the missing link in understanding how global climate change will affect plants in real world soils. Field Crops Research, v.90, p.101-115, 2004. DOI: 10.1016/j.fcr.2004.07.008.

MAATHUIS, F.J.M. Physiological functions of mineral macronutrients. Current Opinion in Plant Biology, v.12, p.250258, 2009. DOI: 10.1016/j.pbi.2009.04.003.

MALAVOLTA, E.; VITTI, G.C.; OLIVEIRA, S.A. de. Avaliação do estado nutricional de plantas: princípios e aplicações. $2^{\text {nd }}$. Piracicaba: Potafos, 1997. 319p.

MENGEL, K.; KIRKBY, E. A. (Ed.). Principles of plant nutrition. $5^{\text {th }}$ ed. Dordrecht: Springer, 2001. 849p. DOI: 10.1007/978-94-010-1009-2.
MOREIRA, A.; MALAVOLTA, E.; HEINRICHS, R.; TANAKA, R.T. Influência do magnésio na absorção de manganês e zinco por raízes destacadas de soja. Pesquisa Agropecuária Brasileira, v.38, p.95-101, 2003. DOI: 10.1590/S0100-204X2003000100013.

NEUHAUS, C.; GEILFUS, C. M.; MÜHLING, K. H. Increasing root and leaf growth and yield in $\mathrm{Mg}$-deficient faba beans (Vicia faba) by $\mathrm{MgSO}_{4}$ foliar fertilization. Journal of Plant Nutrition and Soil Science, v.177, p.741-747, 2014. DOI: 10.1002/ jpln.201300127.

POL, F. van der; TRAORE, B. Soil nutrient depletion by agricultural production in Southern Mali. Fertilizer Research, v.36, p.79-90, 1993. DOI: 10.1007/BF00749951.

RAIJ, B. van; ANDRADE, J.C. de; CANTARELLA, H.; QUAGGIO, J.A. (Ed.). Análise química para avaliação da fertilidade de solos tropicais. Campinas: IAC, 2001. 285p.

REINBOTT, T.M.; BLEVINS, D.G. Response of soybean to foliar-applied boron and magnesium and soil-applied boron. Journal of Plant Nutrition, v.18, p.179-200, 1995. DOI: 10.1080/01904169509364894.

RÖMHELD, V.; KIRKBY, E.A. Magnesium functions in crop nutrition and yield. Cambridge: International Fertiliser Society, 2007. p.151-171. (International Fertiliser Society. Proceeding, n.616).

SANTOS, H.G. dos; JACOMINE, P.K.T.; ANJOS, L.H.C. dos; OLIVEIRA, V.A. de; OLIVEIRA, J.B. de; COELHO, M.R.; LUMBRERAS, J.F.; CUNHA, T.J.F. (Ed.). Sistema brasileiro de classificação de solos. 2.ed. Rio de Janeiro: Embrapa Solos, 2006. 306p.

SOUSA, D.M.G. de; LOBATO, E. (Ed.). Cerrado: correção do solo e adubação. 2.ed. Planaltina: Embrapa Cerrados, 2004. 416p.

TEKLIĆ, T.; VRATARIĆ, M.; SUDARIĆ, A.; KOVAČEVIĆ, V.; VUKADINOVIĆ, V.; BERTIĆ, B. Relationships among chloroplast pigments concentration and chlorophyllmeter readings in soybean under influence of foliar magnesium application. Communications in Soil Science and Plant Analysis, v.40, p.706-725, 2009. DOI: 10.1080/00103620802697939.

VITTI, G.C. Avaliação e interpretação do enxofre no solo e na planta. Jaboticabal: Funep, 1989. 37p.

VRATARIC, M.; SUDARIC, A.; KOVACEVIC, V.; DUVNJAK, T.; KRIZMANIC, M.; MIJIC, A. Response of soybean to foliar fertilization with magnesium sulfate (Epson Salt). Cereal Research Communications, v.34, p.709-712, 2006. DOI: 10.1556/ crc.34.2006.1.177.

WASKOM, R.M.; WESTFALL, D.G.; SPELLMAN, D.E.; SOLTANPOUR, P.N. Monitoring nitrogen status of corn with a portable chlorophyll meter. Communications in Soil Science and Plant Analysis, v.27, p.545-560, 1996. DOI: 10.1080/00103629609369576.

Received on October 5, 2016 and accepted on April 25, 2017

Pesq. agropec. bras., Brasília, v.52, n.12, p.1185-1191, dez. 2017 DOI: $10.1590 / \mathrm{S} 0100-204 \mathrm{X} 2017001200007$ 